QUALITY

Volume 5, Nomor 1, 2017: 57-82

\title{
PROFESIONALITAS GURU PAI DALAM PENGELOLAAN PEMBELAJARAN DI SMA NEGERI 6 YOGYAKARTA
}

\author{
Fifi Nofiaturrahmah \\ STAIN Kudus \\ fifinoviaturrahmah@gmail.com
}

\begin{abstract}
Abstrak
Belajar membutuhkan kreativitas guru dalam pengembangan standar dan kompetensi dasar. kepala sekolah dukungan, guru dan rekan dukungan internal di dalam guru sangat diperlukan dalam pembelajaran PAI. Guru Pendidikan Agama Islam Dalam SMA 6 Yogyakarta mampu mengelola pembelajaran dengan baik. Dengan penguasaan informasi guru teknologi PAI dapat memilih strategi yang tepat dan media dalam pembelajaran. strategi pembelajaran yang lengkap untuk membantu mengatasi perbedaan yang ditemukan dalam siswa dan sarana yang memadai juga mendukung pengelolaan pembelajaran. Guru tidak hanya untuk merencanakan pelajaran tetapi juga untuk dapat tampil baik dan terstruktur. Faktorfaktor yang mendukung kemampuan guru PAI pembelajaran yang paling dominan PAI adalah MGMP. Faktor pembatas adalah kurangnya pengetahuan guru tentang PAI SBC.
\end{abstract}

Kata Kunci: Profesionalisme guru, pembelajaran dan pengelolaan

\section{Abstract}

In Learning takes creativity of teachers in the development of standards and basic competencies. Support principals, teachers and support colleagues internally within the teacher is indispensable in learning PAI. Islamic Education Teachers In senior high school 6 Yogyakarta've been able to manage learning well. With the mastery of information technology teachers PAI able to choose the right strategy and media in learning. Complete learning strategies to help overcome the differences found in the student and sufficient means also supports the management of learning. Teachers not only to plan a lesson but also to be able to perform well and structured. Factors that support the ability of teachers PAI most dominant learning PAI is MGMP. The limiting factor is the lack of teacher knowledge about PAI SBC.

Keywords: teacher professionalism, learning and management

\section{A. Pendahuluan}

Pembelajaran yang menarik adalah pembelajaran yang menyenangkan. Dalam pembelajaran guru harus mampu menciptakan suasana belajar yang menyenangkan karena dibutuhkan agar informasi dapat terekam baik oleh siswa. Salah satu prinsip dalam quantum learning adalah bahwa belajar itu haruslah mengasyikkan dan berlangsung dalam suasana gembira sehingga pintu masuk untuk informasi baru akan lebih lebar dan terekam dengan baik (Mel Silberman, 2001). 


\section{QUALITY}

Volume 5, Nomor 1, 2017: 57-82

Siswa memiliki perbedaan dalam menerima informasi dari guru, ada yang cepat, sedang dan lambat, hal ini menjadi tantangan bagi guru, terutama guru Pendidikan Agama Islam dalam penyampaian materi.

Media yang tepat membantu seorang guru untuk menyampaikan informasi kepada siswa supaya pembelajaran lebih efektif dan efisien. Namun dalam proses belajar itu tidak selalu berjalan sesuai dengan harapan kita, sehingga terjadi suatu kesenjangan antara idealitas dengan realitas, inilah yang disebut masalah.

Menurut Oemar Hamalik, media digunakan dalam rangka lebih mengefektifkan komunikasi dan interaksi antara guru dan siswa dalam proses pembelajaran di sekolah (Beny, 2004). Dalam komunikasi adakalanya penafsiran tersebut berhasil, adakalanya tidak. Penafsiran yang gagal atau kurang berhasil berarti kegagalan dalam memahami apa-apa yang didengar, dibaca, atau dilihat dan diamatinya (Arif, 2005).

Ada beberapa faktor yang menjadi penghambat atau penghalang proses komunikasi. Penghambat tersebut biasa dikenal dengan istilah barriers. Kita kenal adanya hambatan psikologis, seperti minat, sikap, pendapat, kepercayaan, intelegensi, pengetahuan dan hambatan fisik seperti kelelahan, keterbatasan daya indera dan cacat tubuh. Siswa senang terhadap mata pelajaran, topik serta gurunya tentu lain hasil belajarnya dibandingkan dengan yang benci atau tak menyukai semua itu (Arif, 2005). Maka guru harus bisa memahami peserta didik dan memilih strategi yang tepat dalam pembelajaran Pendidikan Agama Islam.

Guru harus mempertimbangkan beberapa aspek dalam tahap pengajaran, diantaranya pengelolaan dan pengendalian kelas serta mempertimbangkan perbedaan individu, karena didalam satu kelas mempunyai murid yang berbeda.

Pemilihan strategi yang tepat dalam pembelajaran PAI sangat penting, karena pelajaran agama yang biasanya membosankan, bisa menjadi sangat menyenangkan apabila seorang guru tidak monoton dalam penyampaian informasi. Jika semakin sering kita mengikuti pelajaran semakin bosan, itu berarti gurunya bukan profil yang profesional (Agus Nggermanto, 2003). Penulis setuju dengan pernyataan tersebut karena guru harus bisa mengelolah kelas, agar dalam pelajaran agama yang kesannya membosankan menjadi menyenangkan. 


\section{QUALITY}

Volume 5, Nomor 1, 2017: 57-82

Pendidikan agama di sekolah diharapkan dapat memperbaiki moral bangsa kita. SMA Negeri 6 Yogyakarta yang notabenenya adalah salah satu sekolah favorit, tidak semua siswanya cepat menerima informasi dari guru, maka guru PAI harus mampu memilih strategi yang tepat dalam pembelajaran. Penulis tertarik meneliti hal ini karena guru PAI bisa menyampaikan pelajaran dengan berbagai strategi yang diharapakan dapat menjadi contoh bagi guru PAI lainnya dan penulis sendiri sebagai calon guru agama Islam.

\section{B. Pembahasan}

Guru menerapkan kurikulum yang telah dirancang pemerintah dan institusi, dan mereka harus mampu mengajarnya walaupun kurikulum itu dibanding kurikulum sebelumnya terdapat banyak perubahan. Guru diminta untuk cepat beradaptasi dengan perubahan itu dengan cara mengikuti penataran, workshop, dan belajar dengan teman se-profesi (Martinis, 2007).

Kemampuan-kemampuan guru profesional :

1. merencanakan program belajar-mengajar.

2. melaksanakan dan memimpin proses belajar-mengajar.

3. menilai kemajuan belajar.

4. menafsirkan dan memanfaatkan berbagai informasi hasil penilaian dan penelitian untuk memecahkan masalah profesional kependidikan(Martinis, 2007).

Belajar tuntas merupakan proses pembelajaran yang dilakukan dengan sistematis dan terstruktur, bertujuan untuk mengadaptasikan pembelajaran pada siswa kelompok besar (pengajaran klasikal), membantu mengatasi perbedaanperbedaan yang terdapat pada siswa, berguna untuk menciptakan kecepatan belajar (rate of program). Belajar tuntas diharapkan mampu mengatasi kelemahankelemahan yang melekat pada pembelajaran klasikal (Martinis, 2007).

Keberhasilan seorang guru di dalam kelas bukan hanya sekedar tercapainya suatu tujuan belajar, akan tetapi keberhasilan guru juga ditentukan sejauhmana mereka mengembangkan kecakapan siswanya, karena guru sebagai change agent. Kurikulum 2006 bertujuan memberdayakan siswa-siswa memiliki kecakapan hidup 


\section{QUALITY}

Volume 5, Nomor 1, 2017: 57-82

(life skill), mampu hidup mandiri, berdikari, berpandangan hidup ke masa depan, yang tidak mengajar berfikir seketika, memiliki fikiran optimistik. Guru harus mengembangkan kreativitas para siswa melalui kecakapan memotivasi dengan iklim belajar yang kondusif (Martinis, 2007). Disini dapat disimpulkan guru harus mampu membuat siswanya aktif dalam pembelajaran dan mampu mengatasi perbedaan individu dalam menerima pelajaran sehingga peserta didik tuntas belajar.

Berdasarkan teori belajar tuntas, maka seorang peserta didik dipandang tuntas belajar jika ia mampu menyelesaikan, menguasai kompetensi atau mencapai tujuan pembelajaran minimal 65\% dari seluruh tujuan pembelajaran (E. Mulyasa, 2002).

SMA Negeri 6 Yogyakarta tidak ada kelas akselerasi ini menunjukkan perbedaan individu tidak diabaikan karena hal ini sesuai dengan pembelajaran tuntas yaitu tidak membeda-bedakan kemampuan individu. Penulis berpendapat guru PAI sudah bisa mengelolah kelas dengan baik apabila siswa sedikit yang mengikuti program remedial, sehingga dalam pembelajaran pentingnya kemampuan guru PAI memilih strategi yang tepat karena bisa membantu siswa dalam pencapaian kompetensi.

a. Pengelolaan Pembelajaran

Pengelolaan adalah pengurusan, penyelenggaraan, manajemen (Badudu dan Sultan Mohammad Zain, 1994). Pengelolaan yang penulis maksud yaitu jadwal kegiatan guru dan siswa yang dapat dilihat dari Rencana Pelaksanaan Pembelajaran yang telah dibuat guru, komponen strategi pembelajaran yaitu peran guru dan siswa, pemilihan strategi dan pelaksanaannya sehingga anak dapat tuntas dalam pembelajaran PAI.

Guru sebagai pengelola pembelajaran (learning manajer), guru berperan dalam menciptakan iklim belajar yang memungkinkan siswa dapat belajar secara nyaman (Wina Sanjaya : 22). Di dalam kegiatan mengelolah interaksi belajar mengajar, guru paling tidak harus memiliki dua modal dasar, yakni kemampuan mendesain program dan keterampilan mengomunikasikan program itu kepada anak didik (Sardiman. A.M, 2003). 
QUALITY

Volume 5, Nomor 1, 2017: 57-82

Guru yang kompeten, juga harus mampu mengelolah program belajar mengajar. Dalam hal ini ada beberapa langkah yang harus ditempuh oleh guru. Langkah-langkahnya adalah sebagai berikut :

1) merumuskan tujuan instruksional/pembelajaran.

2) Mengenal dan dapat menggunakan proses instruksional yang tepat.

3) Melaksanakan program belajar mengajar.

4) Mengenal kemampuan anak didik

5) Merencanakan dan melaksanakan program remidial(Sardiman. A.M, $2003: 165)$.

Salah satu kompetensi guru adalah menggunakan media, Teori tingkah laku (behaviorism theory) ajaran B.F Skinner mempengaruhi penggunaan media dalam kegiatan pembelajaran. Teori ini mendorong orang untuk lebih memperhatikan siswa dalam proses belajar mengajar. Menurut teori ini, mendidik adalah mengubah tingkah laku (Arif S. Sadiman dkk : 9).

Media pendidikan sebagai salah satu sumber belajar yang dapat menyalurkan pesan sehingga membantu mengatasi hal tersebut. Perbedaan gaya belajar, minat, intelegensi, keterbatasan daya indera, cacat tubuh atau hambatan jarak geografis, jarak waktu dan lain-lain dapat dibantu diatasi dengan pemanfaatan media pendidikan(Arif S. Sadiman dkk : 14). Dalam pengelolaan pembelajaran guru harus bisa memilih media yang tepat, karena dengan menggunakan media yang tepat maka perbedaan individu bisa diatasi.

Sebelum guru mengajar dikelas hendaknya guru menyusun Rencana Pelaksanaan Pembelajaran (RPP). RPP pada hakekatnya merupakan perencanaan jangka pendek untuk memperkirakan atau memproyeksi apa yang akan dilakukan dalam pembelajaran. Tugas guru yang paling utama terkait dengan RPP berbasis KTSP adalah menjabarkan silabus ke dalam RPP yang lebih operasional dan rinci, serta siap dijadikan pedoman atau scenario dalam pembelajaran (E.Mulyasa, 2002).

b. Kemampuan Guru

Kemampuan adalah kesanggupan, kekuatan, kekuasaan/kebolehan untuk melakukan sesuatu (Peter Salim \& Yenny Salim,1991: 162). Kemampuan yang penulis maksud adalah guru agama mampu memilih strategi yang tepat dalam 


\section{QUALITY}

Volume 5, Nomor 1, 2017: 57-82

pengelolaan pembelajaran berdasarkan KTSP sehingga tercapainya pembelajaran tuntas. Kompetensi merupakan perpaduan dari pengetahuan, keterampilan, nilai dan sikap yang merefleksikan dalam kebiasaan berpikir dan bertindak (E. Mulyasa, 2002). Kompetensi merupakan kemampuan dan kewenangan guru dalam melaksanakan profesi keguruannya (Moh. Uzer, 2006). Untuk keperluan analisis tugas guru sebagai pengajar, maka kemampuan guru atau kompetensi guru yang banyak hubungannya dengan usaha meningkatkan proses dan hasil belajar dapat diguguskan ke dalam empat kemampuan yakni :

1) merencanakan program belajar mengajar

2) melaksanakan dan memimpin/mengelolah proses belajar mengajar.

3) menilai kemajuan proses belajar mengajar.

4) penguasai bahan pelajaran dalam pengertian menguasai bidang studi atau mata pelajaran yang dipegangnya/dibinanya (Nana Sudjana, 2005).

Guru Agama Islam adalah pendidik yang mempunyai tanggung jawab sebagai guru agama dalam membentuk kepribadian anak didik serta mampu beribadah kepada Allah (Zuhairini, 1983). Hal ini menunjukkan bahwa pentingnya kemampuan guru agama dalam pengelolaan pembelajaran agar dapat menjalankan tugasnya dengan baik.

Pelaksanaan pendidikan agama di sekolah merupakan peraturan perundangundangan yang diatur oleh pemerintah sehingga Pendidikan Agama Islam di Indonesia mempunyai dasar pijakan yang cukup kuat. Dasar-dasar tersebut dapat ditinjau dari segi yuridis, dasar religious, segi sosial psikologis

Secara umum Pendidikan Agama Islam diartikan sebagai upaya sadar dan terencana dalam menyiapkan peserta didik untuk mengenal, memahami, menghayati hingga mengimani bertaqwa dan berakhlak mulia dalam mengamalkan ajaran agama Islam dari sumber utamanya Al-Qur'an dan hadits melalui kegiatan bimbingan, pengajaran, latihan serta pengguanaan pengalaman diikuti tuntutan untuk menghormati penganut agama lain dalam hubungannya dengan kerukunan antar umat beragama dalam masyarakat hingga terwujud kesatuan dan persatuan (Depdiknas, 2003). 


\section{QUALITY}

Volume 5, Nomor 1, 2017: 57-82

Kelompok mata pelajaran agama dan akhlak mulia dimaksudkan untuk membentuk peserta didik menjadi manusia yang beriman dan bertakwa kepada Tuhan Yang Maha Esa serta berakhlak mulia. Akhlak mulia mencakup etika, budi pekerti, atau moral sebagai perwujudan dari pendidikan agama (E. Mulyasa, 2002).

Agama mempunyai peranan yang penting dalam kehidupan manusia Pancasila sebab agama merupakan motivasi hidup dan kehidupan serta merupakan alat pengembangan dan pengendalian diri yang amat penting (Zakiah Daradjat, 2006). Dengan demikian maka tujuan pendidikan ialah untuk membimbing anak agar menjadi insan kamil yang berkepribadian muslim sesuai tuntutan al-Qur'an dan hadits.

\section{Pembelajaran PAI di Kelas XI.}

Pembelajaran berdasarkan KTSP merupakan penerapan pengembangan kurikulum yang dilaksanakan oleh guru dan sekolah dalam aktifitas pembelajaran, sehingga peserta didik dapat menguasai kompetensi tertentu dengan baik. Penguasaan materi disini merupakan hasil interkasinya selama pembelajaran baik itu dengan guru, teman maupun benda yang ada disekelilingnya.

KTSP dikembangkan dengan memperhatikan standar kompetensi dan indikator kompetensi sebagai pedoman penilaian dalam penentuan kelulusan peserta didik dari satuan pendidikan, dan standar isi yang telah disahkan pemerintah. Menurut Bapak Fatoni : Guru harus diberi kebebasan dalam pengembangan program pengajaran asal masih dalam koridor standar isi, kadang dalam standar isi tidak ada tapi dia anggap materi ini penting dan banyak digunakan dalam masyarakat maka harus ajarkan. Kepala sekolah memberi dukungan dengan memberikan fasilitas (Fatoni, 2007).

Masing-masing tahapan membutuhkan strategi yang tepat, sehingga apa yang akan disampaikan dapat diterima dengan baik oleh peserta didik.

Tiga faktor yang mempengaruhi implementasi kurikulum, yaitu :

a) Dukungan kepala sekolah

b) Dukungan rekan sejawat guru

c) Dukungan internal yang datang dari dalam diri guru sendiri (Mulyasa, 2002). 


\section{QUALITY}

Volume 5, Nomor 1, 2017: 57-82

Berbagai faktor tersebut guru merupakan faktor penentu di samping faktor-faktor lain. Dengan kata lain keberhasilan implementasi KTSP sangat ditentukan oleh faktor guru, karena bagaimanapun baiknya sarana pendidikan apabila guru tidak melaksanakan tugas dengan baik, maka hasil pembelajaran tidak akan memuaskan.

Disini terlihat bahwa dukungan kepala sekolah dalam pembelajaran PAI sangat positif, dukungan rekan sejawat seperti MGMP juga mendukung keberhasilan pembelajaran, karena di pertemuan MGMP guru bisa saling bertukar pikiran. Keinginan guru untuk maju dan kreatif serta bisa mengimplementasikannya dalam pembelajaran akan menciptakan kesuksesan bagi anak dan guru.

\section{Pengertian Kompetensi Guru PAI}

Kompetensi berasal dari bahasa Inggris competence yang berarti kecakapan dan kemampuan. Menurut Kamus Besar Bahasa Indonesia, kompetensi adalah kewenangan (kekuasaan) untuk menentukan (memutuskan) sesuatu (Djamarah, 1994). Kalau kompetensi berarti kemampuan atau kecakapan, maka hal ini erat kaitannya dengan kepemilikan pengetahuan, kecakapan atau keterampilan.

Kompetensi juga merupakan perpaduan dari pengetahuan, keterampilan, nilai dan sikap yang direfleksikan dalam kebiasaan berpikir dan bertindak (Mulyasa, 2002).

Makna kompetensi jika merujuk pada SK Mendiknas No. 048/U 2002, dinyatakan sebagai seperangkat tindakan cerdas yang penuh tanggung jawab yang dimiliki seseorang sebagai syarat untuk dianggap mampu oleh masyarakat dalam melaksanakan tugas-tugas di bidang tertentu, di dalam pembelajaran kompetensi merupakan kemampuan dasar serta sikap dan nilai penting yang dimiliki siswa telah mengalami pendidikan dan latihan sebagai pengalaman belajar yang dilakukan secara berkesinambungan.

Kompetensi ini bersifat individual, dinamis dan berkembang secara berkelanjutan sejalan dengan tingkat perkembangan siswa (Akmal Hawi, 2006) Gagasan Norman Dodl Taxonomy for Teacher Competencies yaitu 
a) Kompetensi guru untuk asseing and evaluating students behavior mengenal jiwa anak didik merupakan syarat mutlak dalam proses pembentukan kepribadian individu. Kesulitan-kesulitan dalam kepribadian anak didik itu pada umumnya dapat kita ketahui melalui tingkah laku.

b) Kompetensi guru untuk planning instruction. Instruction di sini dapat diartikan sebagai bahan palajaran/pengajaran. Dalam kompetensi ini di kenal dengan membuat persiapan mengajar.

c) Kompetensi guru untuk conducting or implementing instruction, karena kompetensi ketiga ini memegang peranan penting, karena kompetensi ini mengatur dari kompetensi.

Gordon menjelaskan beberapa aspek atau ranah yang terkandung dalam konsep kompetensi sebagai berikut :

a) Pengetahuan (knowledge); yaitu kesadaran dalam bidang kognitif, misalnya seorang guru mengetahui cara melakukan identifikasi kebutuhan belajar, dan bagaimana melakukan pembelajaran terhadap peserta didik sesuai dengan kebutuhannya.

b) Pemahaman (understanding); yaitu kedalaman kognitif, dan afektif yang dimiliki oleh individu. Misalnya seorang guru yang akan melaksanakan pembelajaran harus memiliki pemahaman yang baik tentang karakteristik dan kondisi peserta didik, agar dapat melaksanakan pembelajaran secara efektif dan efisien.

c) Kemampuan (skill); adalah sesuatu yang dimiliki oleh individu untuk melakukan tugas atau pekerjaan yang dibebankan kepadanya. Misalnya kemampuan guru dalam memilih, dan membuat alat peraga sederhana untuk memberikan kemudahan belajar kepada peserta didik.

d) Nilai (value); adalah suatu standar perilaku yang telah diyakini dan secara psikologis telah menyatu dalam diri seseorang. Misalnya standar perilaku guru dalam pembelajaran (kejujuran, keterbukaan, demokratis, dan lain-lain). 
QUALITY

Volume 5, Nomor 1, 2017: 57-82

e) Sikap (attitude); yaitu perasaan (senang-tidak senang, suka-tidak suka) atau reaksi terhadap suatu rangsangan yang datang dari luar. Misalnya reaksi terhadap krisis ekonomi, perasaan terhadap kenaikan upah dan sebagainya.

f) Minat (interest); adalah kecendrungan seseorang untuk melakukan sesuatu perbuatan. Misalnya minat untuk mempelajari atau melakukan sesuatu (E. Mulyasa, 2002).

Kompetensi guru, maksudnya kemampuan yang tidak boleh tidak dimiliki dan diterapkan oleh seorang guru, sedangkan menurut Depdikbud (1980);

1) Penguasaan bahan pelajaran beserta konsep-konsep dasar keilmuannya.

2) Pengelolaan program belajar-mengajar.

3) Pengelolaan kelas.

4) Penggunaan media dan sumber pembelajaran.

5) Penguasaan landasan-landasan kependidikan

6) Pengelolaan interkasi belajar-mengajar

7) Penilaian prestasi siswa

8) Pengenalan fungsi dan program bimbingan dan penyuluhan.

9) Pengenalan dan penyelenggaraan administrasi sekolah.

g) Pemahaman prinsip-prinsip dan pemanfaatan hasil penelitian pendidikan untuk kepentingan peningkatan mutu pengajaran (E. Mulyasa, 2002).

h) Undang-undang guru dan dosen no 14 tahun 2005 pasal 20 menyatakan dalam melaksanakan tugas keprofesionalan, guru berkewajiban merencanakan pembelajaran, melaksanakan proses pembelajaran yang bermutu, serta menilai dan mengevaluasi hasil pembelajaran(E. Mulyasa, 2002).

Terkait dengan pengelolaan pembelajaran yaitu guru merencanakan pembelajaran dengan membuat Rencana Pelaksanaan Pembelajaran (RPP) sebelum mengajar di kelas, melaksanakan pembelajaran dengan 
QUALITY

Volume 5, Nomor 1, 2017: 57-82

menggunakan metode dan strategi yang tepat, menilai dan mengevaluasi hasil pembelajaran, jika hasil evaluasi rendah maka perlu mengadakan perbaikan.

Guru harus bisa mengelolah kelas agar pembelajaran dapat berjalan lancar, sebelum melaksanakan pembelajaran seorang guru mempersiapkan bahan ajar. Bapak Fatoni yang sudah mengajar selama 13 tahun adalah salah satu guru yang kreatif dalam menyampaikan materi karena Bapak Fatoni sering menggunakan powerpoint dalam penyampaian materi dan metode serta strategi yang digunakan sesuai dengan materi yang diajarkan (Hasil pengamatan penulis tanggal 31 Mei 2007, dikelas XI IPS 1 dan hasil wawancara dengan kepala sekolah SMA N 6 Yogyakarta bapak Suradi tanggal 2 juni 2007).

Hal-hal yang perlu dipahami ketika melakukan proses pembelajaran untuk menuju penguasaan kompetensi :

a) Kegiatan pembelajaran harus menerapkan konsep student centered yakni proses itu berpusat pada siswa, artinya kegiatan belajar mengajar perlu memperhatikan minat, bakat, kemampuan, cara dan strategi belajar, dan motivasi belajar dan latar belakang sosial siswa.

b) Proses belajar mengajar harus mempertimbangkan konsep Learning to do sehingga kegiatan belajar memberikan pengalaman nyata dalam hidup sehari-hari.

c) Proses pembelajaran perlu mengembangkan keingintahuan siswa semangat imajinasi dan semangat bertuhan.

d) Proses pembelajaran harus mengembangkan daya kreatifitas siswa.

e) Proses pembelajaran di sekolah harus mampu menimbulkan kesadaran untuk belajar sepanjang hayat.

f) Proses pembelajaran harus mengembangkan kemampuan menggunakan ilmu pengetahuan dan teknologi (Akmal Hawi, 2006).

Seperti yang terlihat pada pengamatan penulis :

"Hari pertama peneliti mengamati anak-anak kelas XI IPS 1, siang itu kelas tidak teratur karena anak-anak menginginkan pulang lebih awal, mereka meminta Bapak Fatoni untuk menggunakan ruang AVA, tapi ruang tersebut dipakai kelas 
QUALITY

Volume 5, Nomor 1, 2017: 57-82

biologi, anak-anak akhirnya masuk kelas dan mendengarkan penjelasan, namun sebagian siswa memainkan HP, bercerita dengan teman sebangkunya, dan ada yang tidak membawa buku agama. Bapak Fatoni sabar menghadapi anak-anak tersebut dengan berusaha menyapaikan materi semaksimal mungkin. Di akhir pelajaran diberi kesempatan bertanya, ternyata anak-anak ada yang bertanya" ( Hasil pengamatan 31 Mei 2007).

Peneliti berpendapat strategi yang tepat dalam hal ini adalah bagaimana membuat kelas di siang itu menjadi lebih hidup dengan pemainan yang menarik, yang jadi kendala adalah ruang kelas yang sempit karena kursi yang terbuat dari kayu yang membuat kelas tidak bisa diubah, saat mengajar di jam terakhir biasanya anak-anak sudah capek, jadi daya konsentrasinya kurang, namun sebagian anak masih fokus dengan pelajaran terbukti pertanyaan dan jawaban dari mereka tidak ada yang menyimpang dari materi yang sedang dibahas.

Skema dari beberapa akibat yang disebabkan oleh besarnya kelas dan siswa secara individul :

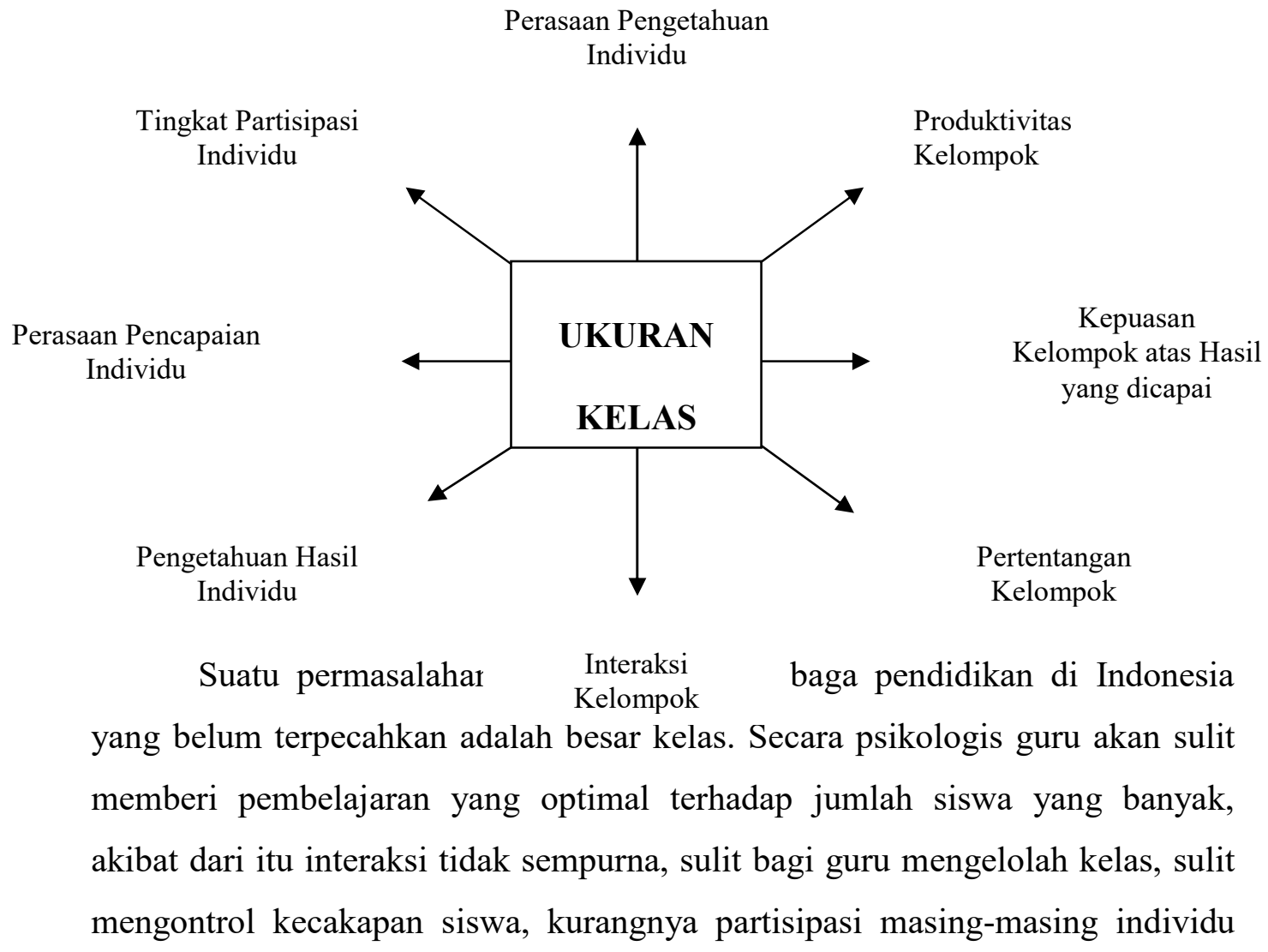


dalam pembelajaran, dan sulit mencapai tujuan pembelajaran (Martinis Yamin, 2007).

Kendala lain yang dihadapi sekolah-sekolah adalah memiliki kursi dan bangku kayu yang banyak memakai ruang belajar, siswa menjadi tidak bebas berkreasi, kelas sulit dimodifikasi, metode pembelajaran yang mendukung pembelajaran berbasis kompetensi tidak dapat dilaksanakan. Metode pembelajaran variatif (metodologycal objective) merupakan bagian terpenting dalam mengimplementasikan kurikulum 2006 (Martinis Yamin, 2007).

Anak-anak apabila pembelajaran kurang menarik, karena suasana ruang kelas monoton, sering tidak memperhatikan gurunya, mereka jarang mengulang pelajaran di rumah karena kesibukan seperti les bahasa Inggris, MIPA, dan lain sebagainya, apabila ada ulangan dadakan, mereka tidak siap, akhirnya mendapat remedial, seperti dalam gambaran berikut ini berikut ini:

"Siang itu Bapak Fatoni mengadakan ulangan harian dadakan, anakanak tidak siap sehingga banyak anak yang mendapat remedial. Satu kelas hanya dua orang yang tidak mendapat remedial. Peneliti mewawancarai salah satu siswa yang tidak mendapat remedial yaitu Grandis Aji Pamungkas karena yang lain langsung diberi tugas oleh Bapak Fatoni. Menurut Grandis Bapak Fatoni sangat menarik dalam menyampaikan materi, yaitu menggunakan powerpoint hampir setiap kali mengajar, kecuali ulangan dan sering menggunakan ruang AVA, walaupun penyampaian diselingi bercanda tapi bercanda benar, apabila ada praktek membungkus mayat dilaksanakan di kelas, Grandis salah satu siswa yang tidak pernah mendapat remedial" (Hasil pengamatan tanggal 2 Juni 2007, pukul 10.30-12.00 di kelas XI IPA 4 dan wawancara pukul 11.35-11.48).

Dari hasil pengamatan dan wawancara dengan Grandis penulis menemukan hal yang bertentangan, penelitian harus lebih mendalam agar terungkap apa yang menjadi masalah sebenarnya.

Dalam suatu proses belajar mengajar tentu saja dikandung suatu harapan agar seluruh atau setidak-tidaknya sebagian besar siswa dapat berhasil baik. Namun kenyataannya sering tidak demikian. Salah satu usaha untuk mencapai hal itu adalah dengan mengembangkan prinsip belajar tuntas atau mastery learning. Belajar tuntas adalah suatu sistem belajar yang 


\section{QUALITY}

Volume 5, Nomor 1, 2017: 57-82

mengharapkan sebagian besar siswa dapat menguasai tujuan istructional umum (basic learning objectives) dari suatu satuan unit pelajaran secara tuntas. Untuk dianggap tuntas diperlukan standar normal (Sardiman A.M, : 167).

Untuk menguasai suatu bahan pelajaran diperlukan waktu yang berbeda-beda bagi setiap siswa. Apabila waktu yang disediakan cukup dan pelayanannya tepat, setiap siswa akan mampu menguasai bahan pelajaran yang diberikan kepadanya. Pemikiran inilah yang mendasari adanya program remedial. Perbaikan biasanya dilaksanakan pada saat-saat setelah evaluasi (Sardiman A.M, : 167-168).

Anak yang mendapat remedial sebenarnya saat Bapak Fatoni menjelaskan mereka mengerti materi yang disampaikan, tetapi apabila sudah lama mereka lupa. Seperti yang diungkapkan oleh Wahyuningsih dalam wawancara saya tanggal 4 Juni 2007 di ruang AVA :

"Strategi yang digunakan Bapak Fatoni sangat menarik, saya mengerti apa yang Bapak Fatoni jelaskan, tapi saat ujian saya lupa, jadi saya pernah mendapat remidi. Bapak Fatoni selalu memberi motivasi, dan doa-doa menjelang ujian."

Disini kita bisa membuat sebuah kesimpulan bahwa setiap anak mempunyai perbedaan dalam belajar. Grandis tidak pernah mendapat remedial saat pelajaran agama, karena dia mengulang pelajaran dirumah dan saat bapak Fatoni menjelaskan dia selalu memperhatikan. Nilai akhir semester ini sangat memuaskan kognitif mendapat nilai 85, psikomotorik 85 dan afektif A.

Belajar sangat membutuhkan motivasi. Motivation is an essential condition of learning. Hasil belajar akan menjadi optimal, kalau ada motivasi. Motivasi akan senantiasa menentukan intensitas usaha belajar bagi para siswa. Ada tiga fungsi motivasi :

a) Mendorong manusia untuk berbuat, jadi sebagai penggerak atau motor yang melepaskan energi. Motivasi dalam hal ini merupakan penggerak dari setiap kegiatan yang akan dikerjakan.

b) Menentukan arah perbuatan, yakni ke arah tujuan yang hendak dicapai. Dengan demikian motivasi dapat memberikan arah dan kegiatan yang harus dikerjakan sesuai dengan rumusan tujuannya. 
QUALITY

Volume 5, Nomor 1, 2017: 57-82

c) Menyeleksi perbuatan, yakni menentukan perbuatan-perbuatan apa yang harus dikerjakan yang serasi guna mencapai tujuan, dengan menyisihkan perbuatan-perbuatan yang tidak bermanfaat bagi tujuan tersebut. Seorang siswa yang akan menghadapi ujian dengan harapan dapat lulus, tentu akan melakukakan kegiatan belajar dan tidak akan menghabiskan waktunya untuk bermain kartu atau membaca komik, sebab, tidak serasi dengan tujuan.

Kaitannya dengan motivasi yang diberikan bapak Fatoni saat akhir pelajaran (Hasil pengamatan tanggal 5 Juni 2007 di ruang lab bahasa). Dibawah ini bagan tentang motivasi belajar dalam kerangka rekayasa guru dan emansipasi kemandirian siswa sepanjang hayat.

\section{Bagan I}

Motivasi Belajar dalam Kerangka Rekayasa Pedagogis Guru dan Emansipasi Kemandirian Siswa Sepanjang Hayat

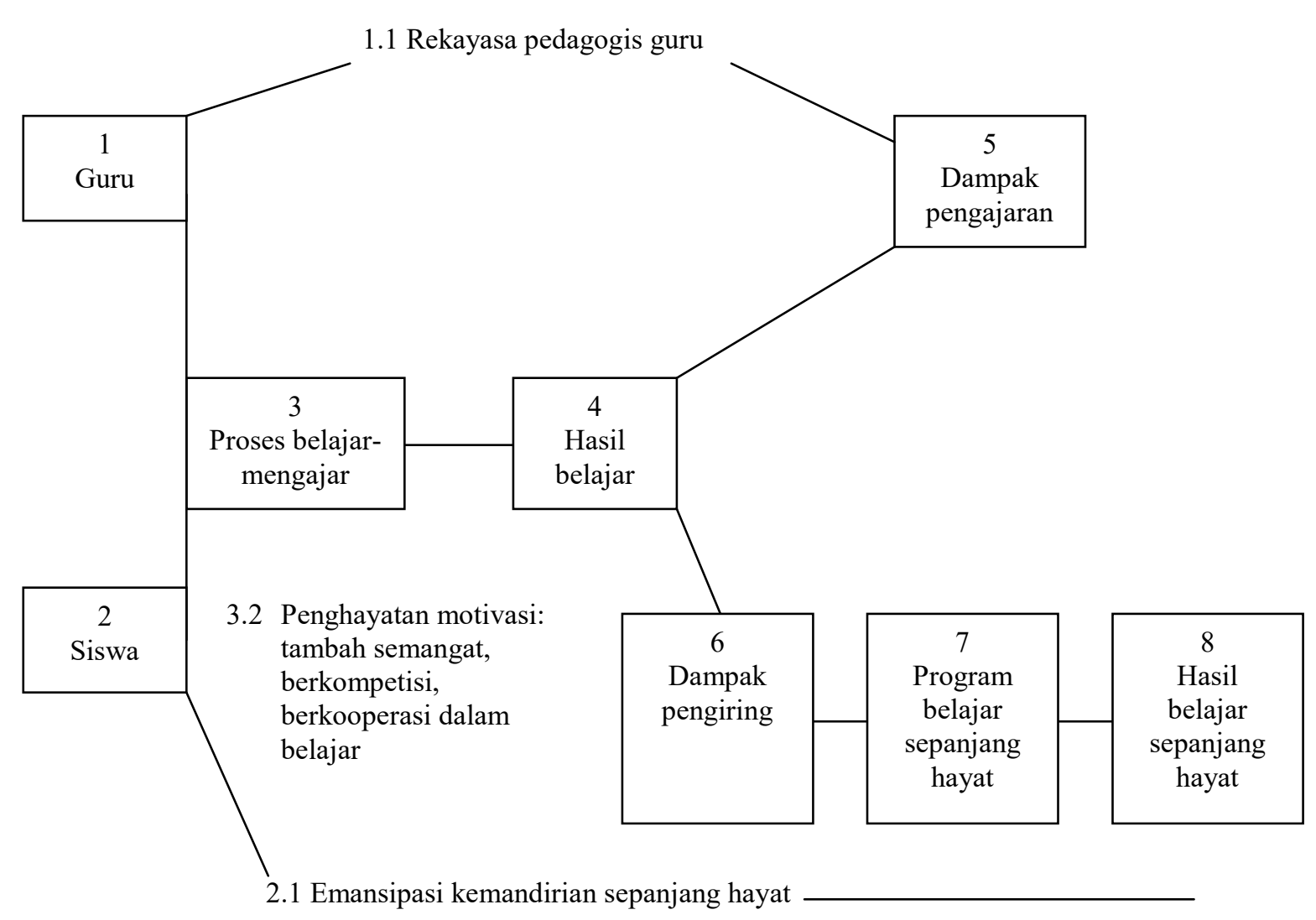


QUALITY

Volume 5, Nomor 1, 2017: 57-82

Bagan ini menurut Schin, Koeswara, Monks, Joyce dan Winkel. (Dimayati dan Mudjiono, 2002). Keterangan :

1) Guru adalah pendidik yang berperan dalam rekayasa pedagogis. Ia menyusun desain pembelajaran, dan dilaksanakan dalam proses belajar-mengajar. Guru bertindak membelajarkan siswa yang memiliki motivasi intrinsik.

2) Siswa adalah pebelajar yang paling berkepentingan dalam menghayati belajar.

3) Dalam proses belajar mengajar, guru melakukan tindakan mendidik seperti memberi nasehat. Tindakan guru tersebut berarti menguatkan motivasi intrinsik. Tindakan guru mendorong siswa belajar suatu tindakan motivasi ekstrinsik. Dampak hal ini siswa "menghayati" motivasi intrinsik atau motivasi ekstrinsik, dan bertambah bersemangat untuk belajar. Sesuai dengan tugas perkembangan, maka siswa dapat bangkit untuk beremansipasi menjadi mandiri. Emansipasi itu berlangsung sepanjang hayat sesuai tingkat pertumbuhan dalam memenuhi kebutuhan pribadi

4) Dengan belajar yang bermotivasi siswa memperoleh hasil belajar.

5) Dampak penganjaran adalah hasil belajar yang segera dapat diukur, yang terwujud dalam nilai rapor. Sebagian besar rekayasa pedagogis guru terwujud sampai dampak pengajaran.

6) Dampak pengiring adalah unjuk kerja siswa setelah mereka lulus ujian atau transfer hasil belajar di sekolah. Dari segi tugas perkembangan jiwa, maka dampak pengiring merupakan unjuk kerja tugas perkembangan untuk mencapai aktualisasi diri secara penuh.

7) Lulusan sekolah diharapkan dapat mengembangkan diri lebih lanjut.

8) Dengan memprogram belajar sendiri secara berkesinambungan, maka ia memperoleh hasil belajar atau tanggung jawab sendiri.

Bapak Fatoni berusaha memberikan anak-anak pengalaman langsung dalam pembelajaran PAI, hal ini diungkapkan salah satu siswi SMA Negeri 6 
QUALITY

Volume 5, Nomor 1, 2017: 57-82

Yogyakarta (Hasil wawancara dengan Wardatul Fitri, kelas XI IPS 2, tanggal 5 Juni 2007) :

"Apabila ada pembelajaran PAI yaitu Memahami ayat-ayat AlQur'an tentang perintah menyantuni kaum dhuafa maka kami disuruh praktek diluar, benar-benar menyantuni kaum dhuafa, saat materi memahami khutbah, tabligh, dan dakwah yang perempuan berdakwah kepada teman 10 orang dan yang laki-laki khutbah jumat, pada saat praktek shalat jenazah kami juga disuruh apabila ada tetangga yang meninggal ikut menyolatkan."

Hal ini bisa membuat anak menjadi orang empati, dan peduli orang lain. Kita bisa melihat strategi yang digunakan bapak Akhmad Fatoni sesuai dengan materi yang diajarkannya. Tapi tidak bisa dihindari apabila masih ada siswa yang mendapat remedial karena seorang guru selain dapat menguasai bahan ajar tapi dituntut bisa mengelolah kelas dengan baik. Perlu disadari bahwa anak didik mempunyai perbedaan yaitu :

\section{a. Perbedaan Kecakapan}

Berdasarkan cepat lambatnya bertindak, maka kecakapan dapat digolongkan menjadi dua yaitu :

1) Kecakapan aktual yaitu kecakapan yang segera dapat dipraktekkan pada setiap saat sebagai hasil usaha belajar yang telah ditempuhnya.

2) Kecakapan potensial yaitu kecakapan yang masih terpendam dalam diri dan bersifat laten. Kecakapan ini diperoleh melalui bawaan sejak lahir yang meliputi kecakapan dasar umum, kecakapan dasar khusus dalam bidang tertentu (talenta) dan intelegensi (kecerdasan). Untuk sekolah Dasar IQ yang diperlukan 80-90, untuk Sekolah Menengah 90-110 sedangkan untuk jenjang perguruan tinggi diperlukan IQ 110keatas.

Dengan bermacam perbedaan dalam diri peserta didik maka peserta didik adalah pribadi yang unik yang mempunyai kesiapan dan kemampuan fisik, psikis serta intelektual yang beragam. Demikian pula halnya dalam proses belajar, setiap peserta didik mempunyai karakteristik yang berbeda.

Demikian juga dalam belajar, dengan berdasar pada kecakapan dasar umum, maka para ahli sepakat membagi kategori pribadi anak menjadi : 
1) Anak superior (supernormal), yaitu anak yang dapat bertindak lebih cepat dan tepat daripada anak sebayanya.

2) Anak rata-rata (normal), yaitu anak yang bertindak biasa-biasa saja dan tidak memiliki kemampuan yang menonjol.

3) Anak dibawah rata-rata (subnormal), yaitu anak-anak yang lambat dalam berpikirnya dikarenakan hal-hal tertentu seperti anak debil.

4) Anak underachiever, yaitu siswa yang mempunyai taraf intelegensi yang tergolong tinggi, akan tetapi memperoleh prestasi belajar yang tergolong rendah. Secara potensial peserta didik yang mempunyai taraf intelegensi yang tergolong tinggi mempunyai kemungkinan besar untuk memperoleh prestasi belajar yang tinggi pula, akan tetapi dikarenakan hal-hal tertentu semacam minat dan motivasi yang kurang sehingga menyebabkan rendahnya prestasi belajar di kelas.

Remedial teaching yang sedianya diperuntukkan bagi sekolah yang memiliki karakteristik tertentu (dalam artian tidak baik, ditunjukkan dengan indikator siswa sering membolos, perkelahian antar pelajar dan lain lain) dengan reputasi sekolah yang tidak berkualiatas, namun di sekolah favorit sekalipun masih butuh program remedial karena kemampuan siswa pada dasarnya berbeda, tentu hal ini masih senada dengan konsep awal remedial teaching yaitu sebagaimana yang dipaparkan oleh Suharsimi yang mengatakan bahwa :

"Kegiatan perbaikan adalah kegiatan yang diberikan kepada siswasiswa yang belum menguasai bahan pelajaran yang diberikan oleh guru, dengan maksud mempertinggi tingkat penguasaan terhadap bahan pelajaran tersebut" (Suharsimi Arikunto, 1986:35).

Dengan adanya konsep diatas, maka program remedial merupakan program layanan yang dilakukan oleh guru untuk menanggulangi kesulitan dalam belajar yang dialami oleh siswa di kelasnya. Bimbingan belajar yang diberikan kepada siswa baik itu secara kelompok bahkan individu yang mengalami kesulitan pribadi, secara ideal merupakan tugas dan kewajiban guru 


\section{QUALITY}

Volume 5, Nomor 1, 2017: 57-82

dengan bantuan personil lainnya yang pelaksanaannya secara berencana sesuai waktu yang telah disediakan.

Aktifitas belajar bagi setiap individu yang tidak selalu berlangsung dengan sempurna atau dengan kata lain tidak terjadi proses belajar dalam diri siswa menunjukkan bahwasannya ada hal-hal yang mempengaruhi proses belajarnya. Hal ini membuktikan teori belajar yang diasumsikan oleh Maslow bahwa andai seseorang telah dapat memenuhi semua kebutuhan yang tingkatannya lebih rendah, maka motivasi akan diarahkan pada terpenuhinya kebutuhan aktualisasi diri yaitu untuk mengembangkan potensi dan bakat yang dimilikinya. Menurut Bapak Fatoni dari hasil wawancara 2 juni 2007 :

" Anak IPA lebih baik nilai ujiannya dibandingkan anak IPS."

Masing-masing pribadi selain mempunyai kekurangan juga memiliki kecerdasan yang berbeda sehingga untuk menerapkan kecerdasan majemuk yang dimiliki peserta didik, para pakar seperti Thomas Armstrong yang dikutip oleh Elaine menjelaskan secara rinci bagaimana menerapkan teori kecerdasan majemuk di kelas (Elaine B. Johnson, 2007).

\section{b. Perbedaan kecerdasan yang dimilikinya}

Kecerdasan tersebut antara lain :

1) Kecerdasan linguistik, mempunyai kecenderungan dengan bahasa dan penggunaannya. Diantara profesi yang berkaitan dengan kecerdasan ini ialah reporter Koran, politisi, penulis.

2) Kecerdasan matematis-logis, berkaitan dengan pola, angka dan logika. Mereka cenderung pintar teka-teki, menggambar. Profesi yang sering digeluti ialah fisikawan, insinyur.

3) Kecerdasan spasial, berhubungan dengan bentuk, lokasi dan membayangkan hubungan. Profesinya antara lain pelukis, dekorator interior.

4) Kecerdasan kinestetik-tubuh, berhubungan dengan pergerakan dan keterampilan tubuh. Orang-orang ini biasanya menjadi atlit, penari balet, pengrajin. 
QUALITY

Volume 5, Nomor 1, 2017: 57-82

5) Kecerdasan musical, berhubungan dengan musik, ritme dan nada. Profesinya ialah penulis lagu, penyanyi, pemain alat musik.

6) Kecerdasan interpersonal, berkaitan dengan mengerti dan menghadapi orang lain. Biasanya mereka seringkali ahli komunikasi dan pintar mengorganisasi. Profesinya ialah hakim, pedagang.

7) Kecerdasan intrapersonal, berkaitan dengan hubungan dan memahami diri sendiri dan senang menekuni aktifitas sendirian. Contohnya psikiater, psikolog.

8) Kecerdasan naturalis, berkaitan dengan kecintaan terhadap alam semesta, dan lebih menyukai konservasi alam. Misalnya ahli zoologi, penjaga hutan dan petualang.

Berdasar ragam kecerdasan diatas, masing-masing anak mempunyai kombinasi dari kecerdasan tersebut dan mempunyai kekuatan relatif dari tiap kecerdasan. Namun kebanyakan sekolah menekankan pada kecerdasan logismatematis dan linguistik dan mengesampingkan siswa dengan kecerdasan lainnya, sehingga ada sebagian siswa tersebut yang kesulitan dalam belajar di sekolah dan tidak terjadi proses belajar yang diharapkan. Maka solusi alternatif yang sangat tepat digunakan untuk menangani siswa manakala tidak terjadi proses belajar dalam kegiatan belajar mengajar ialah dengan dilakukannya perbaikan (remedial teaching), seperti yang telah diterapkan oleh SMA Negeri 6 Yogyakarta.

Remedial teaching bukanlah pekerjaan yang mudah karena beragam kesulitan yang dialami siswa kadang sukar ditemukan solusinya dan kadang juga mudah untuk disembuhkan baik itu oleh guru ataupun juga oleh pihakpihak lain yang berkaitan. Untuk membantu pelaksanaan remedial teaching, guru hendaknya :

1) Memiliki pengetahuan tentang karakteristik murid yang mengalami kesulitan belajar. Berhubungan dengan norma-norma (ukuran) yang dapat menentukan bahwa anak tersebut menderita kesulitan belajar, diantaranya : tujuan pendidikan yang berbeda dengan kemampuan anak dalam menerima pelajaran, kedudukan anak dalam kelompok 
QUALITY

Volume 5, Nomor 1, 2017: 57-82

bila ia menempati urutan terendah dalam kelompoknya, kemampuan siswa sendiri dan yang terakhir adalah kepribadian atau kebiasaan anak.

2) Mencari kemungkinan yang menyebabkan anak tersebut mengalami kesulitan belajar, hal ini berkaitan erat dengan faktor-faktor penyebab kesulitan belajar yang akan dibahas pada bagian berikut.

3) Mempelajari usaha-usaha dan cara menyembuhkan anak-anak yang mengalami kesulitan belajar melalui teknik-teknik seperti wawancara, observasi, angket, meneliti ulangan murid, kunjungan rumah, penelitian kesehatan anak dan penggunaan tes psikologi.

Dengan adanya diagnosa diatas, diharapkan remedial teaching dapat berjalan sesuai dengan tujuannya yaitu menyembuhkan anak-anak yang mengalami kesulitan belajar. Sehingga tujuan pendidikan nasional yang menekankan pada keseimbangan antara berbagai aspek kehidupan manusia baik sebagai individu maupun sebagai warga masyarakat Indonesia tercapai dengan sempurna berkat bantuan program perbaikan (remedial teaching) (Tadjab, 1994).

Perbaikan dan pengayaan dalam SMA Negeri 6 Yogayakarta merupakan program tindak lanjut bagi mereka yang mengalami kesulitan belajar dan bagi mereka yang memerlukan pemahaman lebih lanjut, bedanya kalau perbaikan diperuntukkan bagi mereka yang memiliki skor hasil evaluasi $<7$. 
QUALITY

Volume 5, Nomor 1, 2017: 57-82

\section{Gambar Kurva Normal}

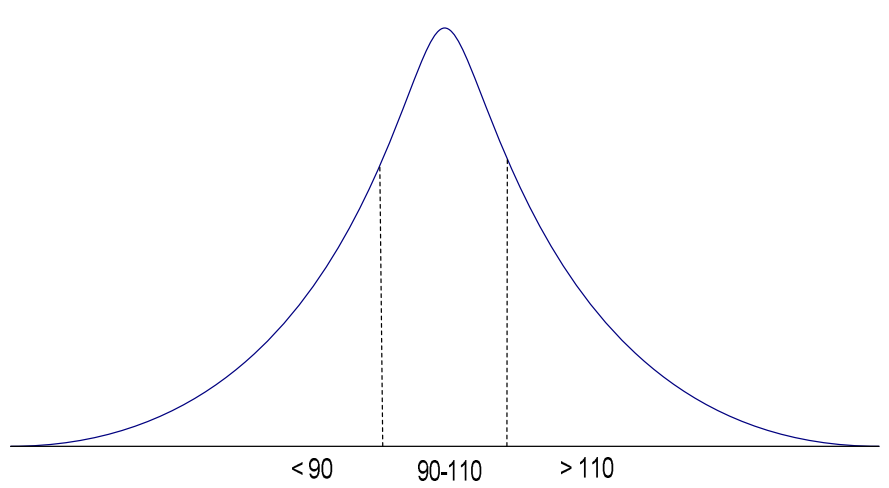

Keterangan IQ :

$$
\begin{aligned}
& <90 \text { : Anak Lambat } \\
& \text { 90-110: Anak Normal } \\
& >110: \text { Anak Pandai }
\end{aligned}
$$

Fungsi program remedial adalah untuk memperlancar proses belajar mengajar sehingga dapat mengurangi beban belajar dan meningkatkan prestasi belajar. Adapun kontribusi remedial teaching bagi siswa antara lain

1) Melalui program remedial, masalah siswa dapat diperbaiki sehingga apa yang diharapkan oleh siswa dan guru dalam proses pembelajaran dapat tercapai secara optimal.

2) Siswa dapat lebih diperhatikan karena program remedial memungkinkan guru dan pihak terkait untuk dapat memperoleh pemahaman yang lebih baik terhadap siswa.

3) Dapat membantu siswa untuk lebih cepat menyesuaikan dirinya terhadap tuntutan kegiatan belajar di kelas akselerasi baik dalam arti waktu maupun materi.

4) Program remedial dapat memperkaya diri siswa dalam proses belajar mengajar baik dari segi materi dan pematangan diri.

5) Membantu siswa untuk dapat beradaptasi dengan dirinya sendiri dalam kegiatan belajar mengajar.

6) Dapat menyembuhkan atau memperbaiki kondisi-kondisi kepribadian siswa yang diperkirakan menunjukkan adanya penyimpangan. 


\section{QUALITY}

Volume 5, Nomor 1, 2017: 57-82

Seorang guru mempunyai tanggung jawab yang besar. Guru tidak hanya mampu mengajar dikelas tapi dapat memberikan contoh yang baik. Tanggung jawab seorang guru bukan hanya di dunia tapi juga di akhirat, beruntunglah jika seorang guru dapat dikenang seorang murid sampai tua, bahkan saat ajal menjemput ada seorang siswanya dulu yang melayat, berarti guru tersebut sangat berarti. Semoga kita dapat menjadi guru yang dikenang karena kebaikan, bukan karena keburukan yang kita lakukan.

\section{Bagan II}

\section{Tugas Guru}

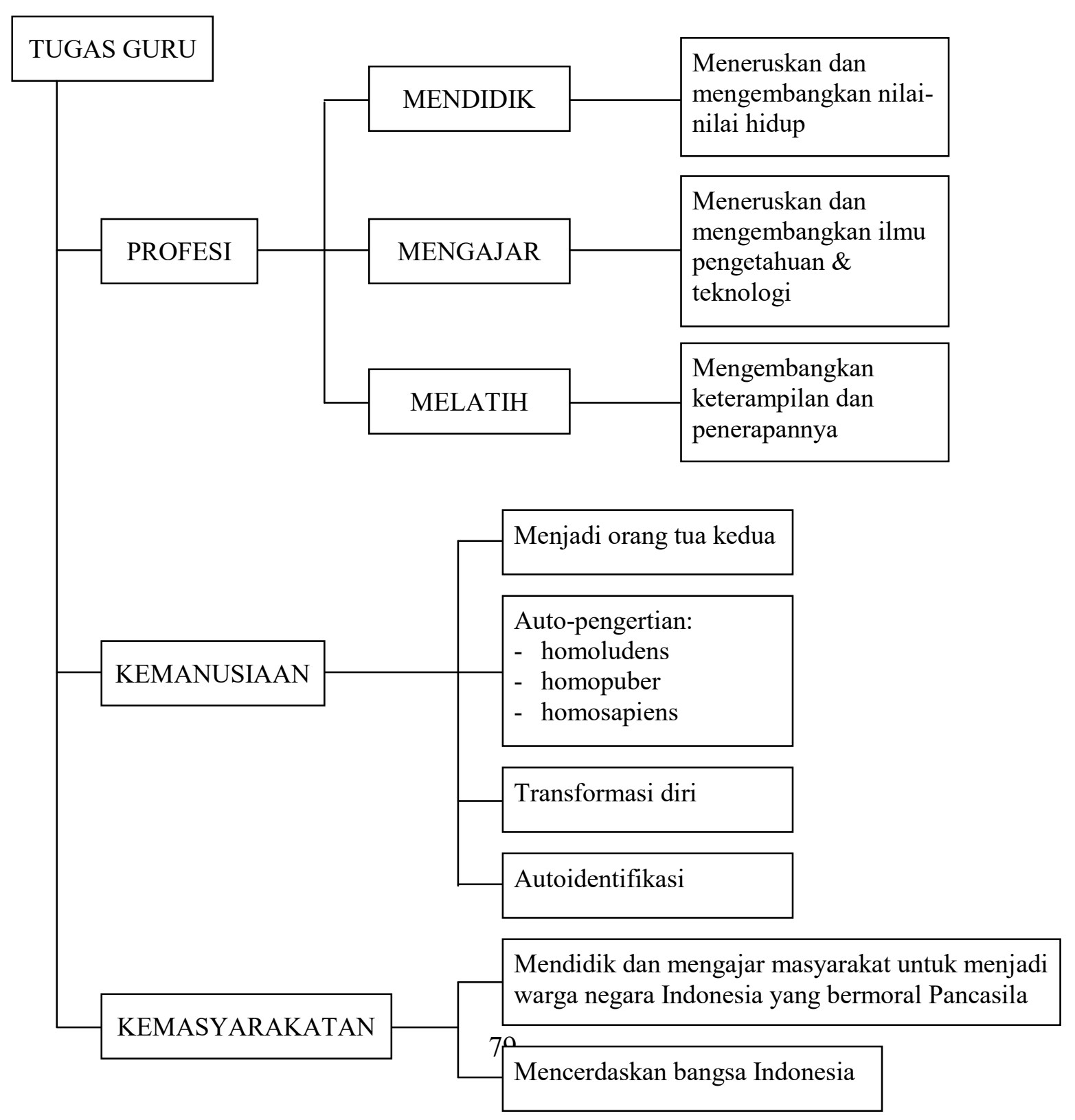


QUALITY

Volume 5, Nomor 1, 2017: 57-82

Proses pembelajaran khususnya yang berlangsung di kelas sebagian besar ditentukan oleh peranan guru, begitu pula halnya di SMA Negeri 6 Yogyakarta ini, peranan guru yang paling dianggap dominan yaitu :

a. Guru sebagai demonstrator, guru hendaknya menguasai materi pembelajaran dan senantiasa mengembangkan kemampuannya dalam bidang ilmu yang dimilikinya, karena hal ini akan sangat menentukan hasil belajar yang dicapai oleh peserta didik terutama bagi anak berbakat.

b. Guru sebagai fasilitator, hal ini erat kaitannya dengan peran sebagai pengelola kelas namun dalam hal ini guru juga harus mampu untuk memberikan kemudahan belajar kepada peserta didik agar dapat membentuk kompetensi dan mencapai tujuan secara optimal.

c. Guru sebagai pengelola kelas, bertanggung jawab memelihara lingkungan fisik kelasnya, agar senantiasa menyenangkan untuk belajar dan mengarahkan serta membimbing proses intelektual, sosial, emosional, moral, dan spiritual dalam kelas, serta mengembangkan kompetensi dan dan kebiasaan bekerja dan belajar secara efektif di kalangan peserta didik.

d. Guru sebagai mediator, bukan hanya sebagai penyampai informasi dalam pembelajaran, tetapi juga sebagai perantara dalam hubungan antar manusia dengan peserta didik.

e. Guru sebagai evaluator, guru harus mampu menilai proses dan hasil belajar yang telah dicapai serta memberikan umpan balik terhadap keefektifan pembelajaran yang telah dilakukan.

\section{Simpulan}

Guru merupakan salah satu faktor penentu tinggi rendahnya mutu hasil pendidikan. Keberhasilan penyelenggaraan pendidikan sangat ditentukan oleh sejauh mana kesiapan guru dalam mempersiapkan peserta didiknya melalui kegiatan belajar-mengajar. Namun demikian, posisi strategis guru untuk meningkatkan mutu hasil pendidikan sangat dipengaruhi oleh kemampuan profesional mengajar dan tingkat kesejahteraannya. Disamping mengikuti MGMP dan KKG untuk menemukan 


\section{QUALITY}

Volume 5, Nomor 1, 2017: 57-82

solusi terhadap berbagai masalah dalam pembelajaran, dalam KTSP guru juga harus mampu bekerja mandiri untuk memperbaiki diri dalam pembelajaran. Hal ini penting agar ia benar-benar menjadi guru yang mampu digugu dan ditiru.

\section{DAFTAR PUSTAKA}

Agus Nggermanto (2003) Quantum Quotient, Bandung : Nuansa.

Akmal Hawi (2006). Kompetensi Guru PAI, Palembang : IAIN Raden Fatah Press.

Arif S. Sadiman dkk, (2005). Media Pendidikan : Pengertian, Pengembangan dan Pemanfaatannya, Jakarta : PT Raja Grafindo Persada.

Benny A. Pribadi \& Yuni Katrin (2004). Media Teknologi, Jakarta : Universitas Terbuka.

Dimayati dan Mudjiono (2002). Belajar dan Pembelajaran, Jakarta : Rineka Cipta.

Depdiknas (2003). Kurikulum Pendidikan Agama Islam SMU 2004, Jakarta : Depdiknas.

Elaine B. Johnson (2007). Contextual Teaching and Learning, penerjemah : Ibnu Setiawan, Bandung : Mizan Media Utama.

E. Mulyasa (2002). KBK, Konsep, Karakteristik dan Implementasi. Bandung : PT Remaja Rosdakarya.

Martinis Yamin (2007). Profesionalisasi guru dan implementasi KTSP, Jakarta : Gaung Persada Press.

Mel Silberman (2001). Active Learning : 101 Strategi Pembelajaran Aktif, Yogyakarta : YAPPENDIS. 2001.

Moh. Uzer Usman (2006). Menjadi Guru Profesional, Bandung : PT Remaja Rosdakarya.

Nana Sudjana (2005). Dasar-Dasar Proses Belajar Mengajar, (Bandung : Sinar Baru Algensindo.

Peter Salim \& Yenny Salim (1991). Kamus Bahasa Indonesia Kontemporer. Jakarta : Modern English Press. 


\section{QUALITY}

Volume 5, Nomor 1, 2017: 57-82

Sardiman A.M. (2003). Interaksi dan Motivasi Belajar Mengajar, (Jakarta : Raja Grafindo Persada.

Suharsimi Arikunto (1986). Pengelolaan Kelas dan Siswa; Sebuah Pendekatan Evaluatif, Jakarta : Rajawali, 1986.

Syaiful Bahri Djamarah (2000). Guru dan Anak Didik dalam Interaksi Edukatif, Jakarta : Rineka Cipta.

Zuhairini, dkk. (1983). Metodik Khusus Pendidikan Agama, Surabaya : Usaha Nasional, 1983.

Zakiah Daradjat (2006). Ilmu Pendidikan Islam, Jakarta : Bumi Aksara. 